\title{
LIQUID HOT WATER AND STEAM EXPLOSION PRETREATMENT OF SUGARCANE BAGASSE FOR ENZYME PRODUCTION BY A SEQUENTIAL SOLID-STATE AND SUBMERGED METHOD
}

\author{
F. M. CUNHA ${ }^{1,2,3}$, A. BADINO ${ }^{2}$, C. S. FARINAS ${ }^{3}$, E. XIMENES ${ }^{1}$ and M. R. LADISCH ${ }^{1}$ \\ ${ }^{1}$ Purdue University, Laboratory of Renewable Resources Engineering \\ ${ }^{2}$ Federal University of São Carlos, Department of Chemical Engineering \\ ${ }^{3}$ EMBRAPA Instrumentacao \\ E-mail para contato: cunha_fm@yahoo.com.br
}

\begin{abstract}
RESUMO - The use of sugarcane bagasse on enzyme production is a promising alternative for reducing the costs of second generation ethanol. However, a pretreatment step is required to increase cellulose and hemicellulose accessibility. Here, the influence of Liquid Hot Water (LHW) and steam explosion (SE) pretreatments in cultivations with three Aspergillus strains were investigated. A new sequential method was carried out with a first step in solid-state for $24 \mathrm{~h}$, followed by the transition to submerged cultivation and enzyme production in the presence of $1 \%(\mathrm{w} / \mathrm{v})$ of sugarcane for $72 \mathrm{~h}$. For both A. niger strains, the endoglucanase production was 20 to $50 \%$ higher in cultivations with steam exploded sugarcane bagasse. The xylanase and $\beta$-glucosidase production, however, were higher in LHW pretreated sugarcane bagasse, with xylanase production around $23 \%$ higher and $\beta$-glucosidase up to 4 -fold higher. The A. niger A12 strain produced the higher titers of all enzymes evaluated, resulting in 1.26; $26.25 ; 3.70$ and $0.58 \mathrm{IU} . \mathrm{mL}^{-1}$ of endoglucanase, xylanase, $\beta$-glucosidase and $\beta$ xylosidase, respectively, in LHW bagasse. Pretreated bagasse is not suitable for enzyme production by $A$. oryzae $P 27 C 3$, indicating that this strain may be more sensitive to possible inhibitory products released from both pretreatments.
\end{abstract}

\section{INTRODUCTION}

The enzymatic hydrolysis of lignocellulosic feedstocks is a promising route compared to chemical approaches due to its lower environmental impact (Sukumaran et al., 2009). In order to ensure that enzymatic hydrolysis will be effective to convert lignocellulosic substrates in sugars, the utilization of specific enzymatic extracts is needed. However, the high costs of cellulases production combined to low specific enzyme activities limits its industrial application (Kocher et al., 2008).

Recent research related to the source of the enzymatic extracts applied to the hydrolysis of lignocellulosic materials have shown that the extracts produced in the presence of lignocellulosic derived inducers instead of commercial substrates result in better hydrolysis performance due to their specificity to the substrate (Castro et al., 2010; Singh et al., 2009). 
Enzymatic extracts produced by different microbial strains also have different effects in the hydrolysis of these materials (Maeda et al., 2011).

Due to the complexity and strength of the lignocellulosic materials, its use in cultivations for cellulase and xylanase production may require, at first, a pretreatment step in order to render the cellulose fraction more accessible to the fungi. Pretreatment can positively impact not only enzyme production, but also the hydrolysis of lignocellulosic materials (Wyman et al., 2011; Ladisch, 2010).

In Brazil, the main lignocellulosic material used for enzyme and cellulosic ethanol production is the sugarcane bagasse, due to its availability in sugarcane mills. Among the chemical and physical pretreatments that can be used for sugarcane bagasse pretreatment, the Steam Explosion (SE) and the Liquid Hot Water (LHW) pretreatments has gained attention as they enable the increase of cellulose digestibility through sugar extraction without the necessity of chemical compound additions (Kohlmann et al, 1994; Mosier et al., 2005, Kim et $a l ., 2009$ a). Furthermore, the LHW pretreatment results in higher preservation of xylan than the SE pretreatment.

The cultivation methods for cellulase production can be divided into solid-state fermentation (SSF) and submerged fermentation $(\mathrm{SmF})$, and each one has advantages or not according to the desired application. In view of the technological demand for strategies to improve the production of cellulase using sugarcane bagasse, a new cultivation method that combines both SSF and SmF processes has been developed; this new sequential solid-state and submerged fermentation method using sugarcane bagasse as substrate has shown promising results (Cunha et al., 2012).

The aim of this research project has therefore been to evaluate the impact of SE and LHW pretreatments on endoglucanase and xylanases production by three different strains of Aspergillus sp. from the Brazilian biome through the sequential fermentation method using sugarcane bagasse as inducer substrate.

\section{MATERIAL AND METHODS}

\subsection{Substrate}

The inducer substrate used was sugarcane bagasse. The stem exploded sugarcane bagasse (SSB) was provided by CTC (Piracicaba, Brazil). It was pretreated at $17 \times 10^{5} \mathrm{~Pa}, 205{ }^{\circ} \mathrm{C}$ for 20 min. The liquid hot water pretreated sugarcane bagasse (LHW) was pretreated on the Laboratoy of Renewables Engineering and Resources (LORRE) using stainless steel tubes $(2.54 \mathrm{~cm}$ diameter $\times 2.1 \mathrm{~mm}$ wall thickness $\times 11.4 \mathrm{~cm}$ long) fitted with a pair of 1 in Swagelok tube end fittings (Swagelok, Solon, OH) (Kim et al., 2009b). The bagasse was heated at 190 ${ }^{\circ} \mathrm{C}$ by placing the tube in a Tecam® SBL-1 fluidized sand bath (Cole-Parmer, Vernon Hills, IL) at $190{ }^{\circ} \mathrm{C}$ for $20 \mathrm{~min}(5 \mathrm{~min}$ heat-up time and $15 \mathrm{~min}$ hold time). After that, the tube was cooled by placing it in water. The pretreated material was dried at $40^{\circ} \mathrm{C}$ and stored until use. The compositions of both sugarcane bagasse samples (Table 1) were determined following the NREL procedure.

\subsection{Microorganisms}


Three Aspergillus strains were used for enzyme production: A. niger A12 (wild strain isolated from black pepper); A. oryzae P27C3 (wild strain isolated from the soil of Amazon forest) and A. niger 3T5B8 (morphological mutant, Couri and Farias, 1995). All strains are deposited at the Embrapa Food Technology microorganism collection in Rio de Janeiro, Brazil.

\subsection{Nutrient medium}

The nutrient medium used for pre-culture and enzyme production was adapted from Mandels and Sternberg (1976), and contained (w/v): $0.14 \%\left(\mathrm{NH}_{4}\right)_{2} \mathrm{SO}_{4}, 0.20 \% \mathrm{KH}_{2} \mathrm{PO}_{4}$, $0.03 \% \mathrm{CaCl}_{2}, 0.02 \% \mathrm{MgSO}_{4} .7 \mathrm{H}_{2} \mathrm{O}, 0.50 \%$ peptone, $0.20 \%$ yeast extract, $0.03 \%$ urea, $0.10 \%$ Tween 80 and $0.10 \%$ of salt solution $\left(5 \mathrm{mg} / \mathrm{L} \mathrm{FeSO}_{4} \cdot 7 \mathrm{H}_{2} \mathrm{O}, 1.6 \mathrm{mg} / \mathrm{L}, \mathrm{MnSO}_{4} \cdot \mathrm{H}_{2} \mathrm{O}, 1.4 \mathrm{mg} / \mathrm{L}\right.$ $\mathrm{ZnSO}_{4} .7 \mathrm{H}_{2} \mathrm{O}$, and $2.0 \mathrm{mg} / \mathrm{L} \mathrm{CoCl}_{2}$ ). The nutrient media was supplemented with sugarcane bagasse according to each experiment condition, described in the next sections.

\subsection{Sequential solid-state and submerged fermentation (SF)}

In the sequential cultivation method experiments, the pre-culture was initiated as SSF, using sugarcane bagasse as substrate. A volume of spore suspension resulting in a concentration of $10^{7}$ spores per gram of bagasse was added, and the cultivation was kept as SSF under static conditions for $24 \mathrm{~h}$ at $32{ }^{\circ} \mathrm{C}$. Then, a volume of nutrient medium enriched with $30 \mathrm{~g} / \mathrm{L}$ of glucose was added (40 parts of nutrient medium per gram of dry solid), and the cultivation was continued as $\mathrm{SmF}$ in an orbital shaker incubator for $48 \mathrm{~h}$ at $32{ }^{\circ} \mathrm{C}$ and 200 $\mathrm{rpm}$. For enzyme production, a volume of pre-culture suspension corresponding to $10 \%(\mathrm{v} / \mathrm{v})$ was transferred to the culture and incubated for $32{ }^{\circ} \mathrm{C}$ and $200 \mathrm{rpm}$ for $72 \mathrm{~h}$. The culture medium for enzyme production in SF was the same described in section 2.3, enriched with 10 $\mathrm{g} / \mathrm{L}$ of glucose and $1 \%(\mathrm{w} / \mathrm{v})$ of sugarcane pretreated bagasse. After cultivation, the samples were filtrated and enzyme assays were performed.

\subsection{Enzyme assays}

Endoglucanase activity was assayed according to the IUPAC (Ghose, 1987) procedure, in the presence of $1 \%(\mathrm{w} / \mathrm{v})$ low viscosity carboxymethyl cellulose in $50 \mathrm{mM}$ sodium citrate buffer $\mathrm{pH} 4.8$. The xylanase activity was determined according to the IUPAC procedure, in the presence of $1 \%(\mathrm{w} / \mathrm{v})$ oat spelts xylan in $50 \mathrm{mM}$ sodium citrate buffer $\mathrm{pH}$ 4.8. One unit of endoglucanase or xylanase activity was defined as the amount of enzyme that released $1 \mu \mathrm{mol}$ of reducing sugar per min under the assay conditions. The reducing sugars concentration was determined by the DNS method. The $\beta$-glucosidase and $\beta$-xylosidase contents were determined in the presence of p-nitrophenyl substrates (Dien et al., 2008).

\section{RESULTS AND DISCUSSION}

Compositional analysis of the sugarcane bagasse: The composition of the sugarcane bagasse after SE and LHW pretreatments (Table 1), as well as the components extracted by water after each pretreatment, are showed in Tables 1 and 2, respectively. 
Table 1 - Composition of sugarcane bagasse after SE and LHW pretreatments

\begin{tabular}{|l|c|c|}
\hline \multicolumn{1}{|c|}{ Components } & $\begin{array}{c}\text { Steam-exploded } \\
\text { sugarcane bagasse }\end{array}$ & $\begin{array}{c}\text { Liquid hot water } \\
\text { sugarcane bagasse }\end{array}$ \\
\hline C-6 carbohydrates (\%) & $71.2 \pm 1.7$ & $69.8 \pm 0.8$ \\
\hline C-5 carbohydrates (\%) & $0.5 \pm 0$ & $1.9 \pm 0.1$ \\
\hline lignin (\%) & $22.8 \pm 2.0$ & $21.9 \pm 2.1$ \\
\hline ashes (\%) & $2.9 \pm 0$ & $1.1 \pm 0.1$ \\
\hline acetate (\%) total & $0 \pm 0$ & $0.3 \pm 0$ \\
\hline \multicolumn{2}{|c|}{$\mathbf{9 7 \pm 4}$} & $\mathbf{9 4} \pm \mathbf{3}$ \\
\hline
\end{tabular}

It can be seen on Table 1 that the lignin and also the C-6 carbohydrates contents are present in the same rate after SE and LHW pretreatments. However, the C-5 carbohydrates rate is higher in LHW bagasse, which may explain a higher xylanase production in cultivations with this bagasse. While SE pretreatment released a higher amount of sugars as glucose, xylose and cellobiose, the LHW pretreatment conserved the xylooligomers fraction (Table 2).

Table 2 - Components released in the hot-washing water after SE and LHW pretreatments

\begin{tabular}{|l|c|c|}
\hline \multicolumn{1}{|c|}{ Components } & $\begin{array}{c}\text { Steam-exploded } \\
\text { sugarcane bagasse }\end{array}$ & $\begin{array}{c}\text { Liquid hot water } \\
\text { sugarcane bagasse }\end{array}$ \\
\hline cellobiose $\left(\mathrm{g} \cdot \mathrm{L}^{-1}\right)$ & 0.09 & 0,00 \\
\hline glucose $\left(\mathrm{g} \cdot \mathrm{L}^{-1}\right)$ & 0.14 & 0.05 \\
\hline xylose $\left(\mathrm{g} \cdot \mathrm{L}^{-1}\right)$ & 0.75 & 0.45 \\
\hline arabinose $\left(\mathrm{g} \cdot \mathrm{L}^{-1}\right)$ & 0.09 & 0.26 \\
\hline acetic acid $\left(\mathrm{g} \cdot \mathrm{L}^{-1}\right)$ & 0.04 & 0.06 \\
\hline lactic acid $\left(\mathrm{g} \cdot \mathrm{L}^{-1}\right)$ & 0,06 & 0,00 \\
\hline xylooligomers $\left(\mathrm{g} \cdot \mathrm{L}^{-1}\right)$ & 2,10 & 4,10 \\
\hline
\end{tabular}

Enzyme production: It was observed that both A. niger strains can grow on pretreated sugarcane bagasse and produce endoglucanase, xylanase and $\beta$-glucosidase. The enzymes profile, however, were impacted differently according to the pretreatment. All the sequential solid-state and submerged cultivations were performed in quintuplicates and the extracts were combined for following experiments. In this sense, the results presented are the enzyme activities of the total five cultivation broths.

Figure 1 shows the endoglucanase production for the six conditions evaluated (cultivations with A. niger A12, A. niger 3T5B8 and A. oryzae P27C3 using LHW and SE bagasse). It is possible to observe that the endoglucanase production can be up to $20 \%$ and $50 \%$ higher in cultivations with SE pretreated sugarcane bagasse, by A. niger A12 and A. niger 3T5B8, respectively. Once both SE and LHW sugarcane bagasse have similar contents 
of C-6 carbohydrates, the higher xylooligomers concentration on LHW sugarcane bagasse and other oligosaccharides, as well as phenolic components released during LHW pretreatment, caused the inhibition of the endoglucanase secreted to the medium. The same effect was observed by Ximenes et al. (2010, 2011).

An opposite effect was observed regarding xylanase (Figure 2) and $\beta$-glucosidase production (Figure 3). The LHW pretreated sugarcane bagasse provided more favorable cultivation conditions for higher xylanase and $\beta$-glucosidase production. For the A. niger strains, the xylanase production was up to $23 \%$ higher when LHW bagasse was used instead of SE bagasse. The $\beta$-glucosidase production by A. niger A12 was 4-fold higher when LHW was used as substrate.

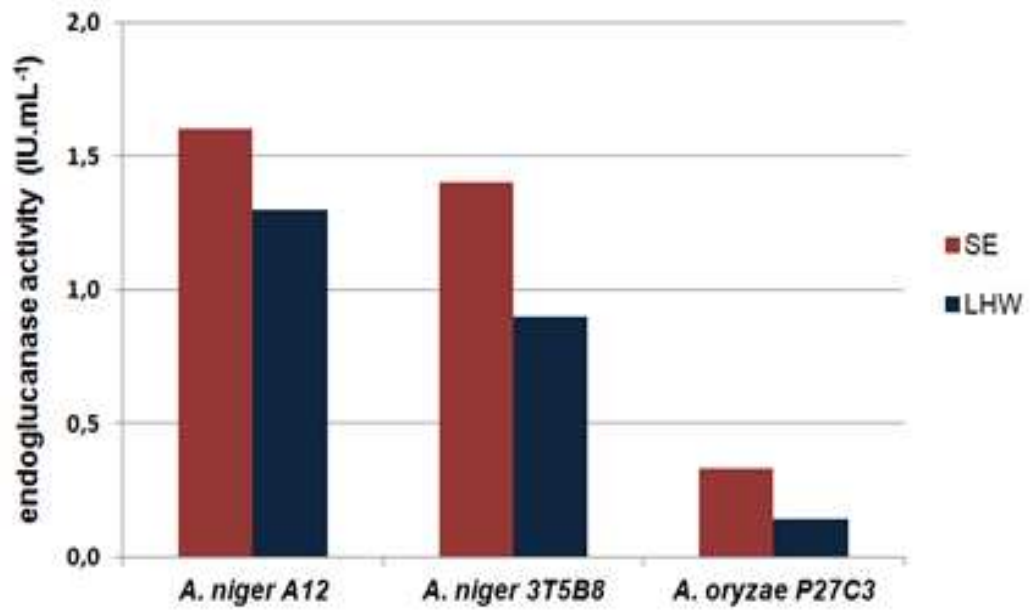

Figura 1 - Endoglucanase production after $72 \mathrm{~h}$ of sequential solid-state and submerged fermentation by three Aspergillus strains growing on steam-exploded (SE) and liquid hot water (LHW) pretreated sugarcane bagasse

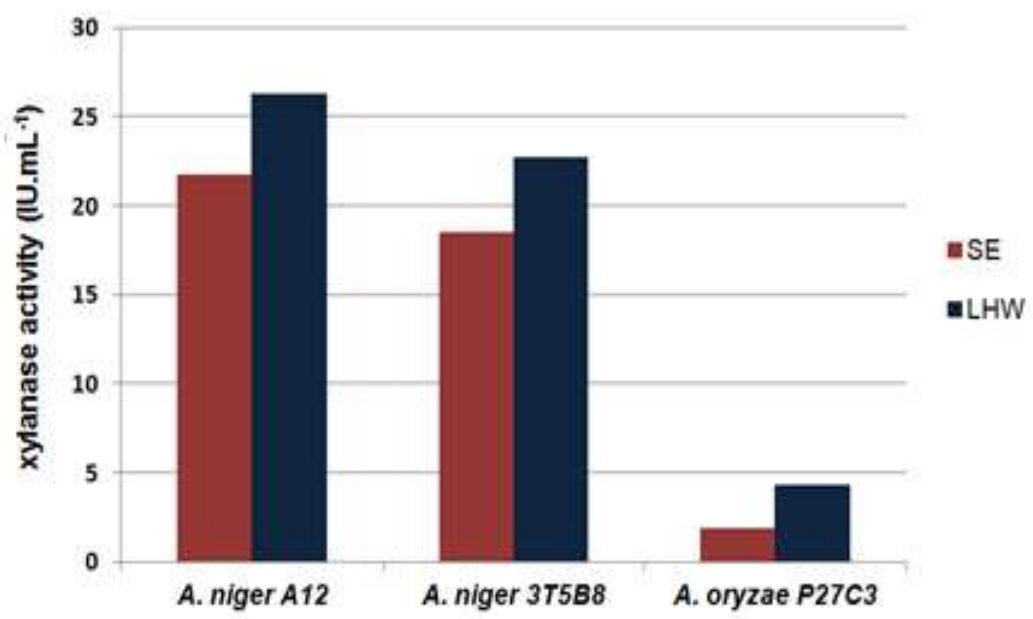

Figura 2 - Xylanase production after $72 \mathrm{~h}$ of sequential solid-state and submerged fermentation by three Aspergillus strains growing on steam-exploded (SE) and liquid hot water (LHW) pretreated sugarcane bagasse 


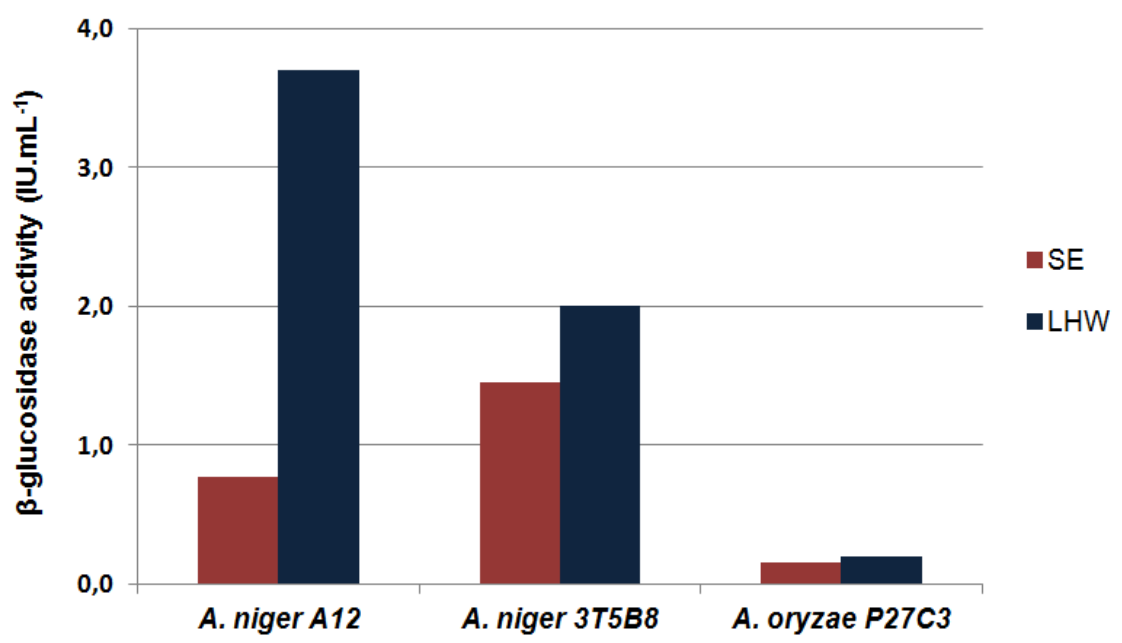

Figura 3 - Xylanase production after $72 \mathrm{~h}$ of sequential solid-state and submerged fermentation by three Aspergillus strains growing on steam-exploded (SE) and liquid hot water (LHW) pretreated sugarcane bagasse

The A. niger A12 strain produced higher titers of all enzymes evaluated, resulting in $1.26 ; 26.25 ; 3.70$ and $0.58 \mathrm{IU} \cdot \mathrm{mL}^{-1}$ of endoglucanase, xylanase, $\beta$-glucosidase and $\beta$ xylosidase, respectively, in LHW bagasse. These results were obtained under the new sequential solid-state and submerged cultivation method, and are promising in comparison to those which Rodríguez-Zúñiga et al. (2014) obtained under conventional solid-state fermentation using the same A. niger A12 strain and LHW pretreated sugarcane bagasse, which resulted in endoglucanase and xylanase activities of 0.75 and 1.31 IU.mL ${ }^{-1}$, respectively.

The A. oryzae P27C3 strain, however, was not able to produce high enzyme titers on pretreated bagasse. This strain was recently isolated from the Amazon forest soil and it has been showed to be more sensitive to the products released during the sugarcane pretreatment. However, even in low titers, the enzyme production profile followed the same trend as observed for the A. niger strains.

\section{CONCLUSION}

For the three Aspergillus sp., while the endoglucanase production was favored by the SE pretreatment, the xylanase and $\beta$-glucosidase production were higher in LHW bagasse cultivations. However, the $A$. oryzae could not produce high enzymatic titers, indicating that this strain (or enzymes secreted in medium) is more sensitive to possible inhibitory products released from both pretreatments. The higher enzyme production was achieved by A. niger A12 in LHW cultivation, resulting in $1.26 ; 26.25 ; 3.70$ and $0.58 \mathrm{IU}_{\mathrm{mL}} \mathrm{m}^{-1}$ of endoglucanase, xylanase, $\beta$-glucosidase and $\beta$-xylosidase respectively.

\section{ACKNOWLEDGEMENTS}

CAPES Foundation, Ministry of Education of Brazil. "PDSE/CAPES Scholarship - Process no 12470-12-0" and to FAPESP (Proc. 2011/23807-1). 


\section{REFERENCES}

CASTRO, A.M.; ALBUQUERQUE DE CARVALHO, M.L.; LEITE, S.G.F.; PEREIRA JR, N. Cellulases from Penicillium funiculosum: production, properties and application to cellulose hydrolysis. J. Ind. Microbiol. Biotechnol v.37, p.151-158, 2010.

COURI, S.; FARIAS, A. X. Genetic manipulation of Aspergillus niger for increased synthesis of pectinolytic enzymes. Revista de Microbiologia, v. 26, n. 4, p. 314-317, 1995.

CUNHA, F.M.; ESPERANÇA, M.N.; ZANGIROLAMI, T.C.; BADINO, A.C.; FARINAS, C.S. Sequential solid-state and submerged cultivation of Aspergillus niger on sugarcane bagasse for the production of cellulase. Bioresour. Technol. v. 112, p. 270-274, 2012.

DIEN B. S.; XIMENES E. A.; O'BRYAN P. J.; MONIRUZZAMAN M.; LI XIN-LI; BALAN V.; DALE, B.; COTTA, M. A. Enzyme characterization for hydrolysis of AFEX and liquid hot-water pretreated distillers' grains and their conversion to ethanol. Bioresour Technol. v. 99(12), p. 5216-25, 2008.

GHOSE, T. K. Measurement of cellulase activities. Pure Applied Chemistry. v. 59, p. 257268, 1987.

KIM, Y.; HENDRICKSON, R.; MOSIER, N. S.; LADISCH, M. R. Liquid Hot Water Pretreatment of Cellulosic Biomass. Methods in Mol. Biol. v.581, p. 93-102, 2009a.

KIM, Y.; MOSIER, N. S.; LADISCH, M. R. Enzymatic Digestion of Liquid Hot Water Pretreated Hybrid Poplar. Biotech. Progr, v.25(2), p. 340-348, 2009 b.

KOCHER, G. S.; KALRA, K. L.; BANTA, G., Optimization of cellulase production by submerged fermentation of rice straw by Trichoderma harzianum Rut-C 8230.The Internet $J$ Microbiol. v. 5. n.2, 2008.

KOHLMANN, K.; WESTGATE, P. J.; WEIL, J.; LADISCH, M. R. Biological-Based Systems for Waste Processing. SAE Technical Paper 932251, SAE Transactions. v. 102-1, p. 1476-1483, 1994.

LADISCH, M. R. Bioenergy: Renewable Liquid Fuels. In "Bio Inspired Innovation and National Security" R. E. Armstrong, M. D. Drapeau, C. A. Loeb, J. J. Valdes (Eds.), Center for Technology and National Security Policy, National Defense University. p. 119-138, 2010.

MAEDA, R. N.; SERPA, V. I.; ROCHA, V. A. L.; MESQUITA, R. A. A.; SANTA ANNA, L.M. M.; DE CASTRO, A. M.; DRIEMEIER, C. E.; PEREIRA JR, N.; POLIKARPOV, I. Enzymatic hydrolysis of pretreated sugarcane bagasse using Penicillium funiculosum and Trichoderma harzianum cellulases. Process Biochemistry. v. 46, p. 1196-1201, 2011.

MANDELS, M.; STERNBERG, D. Recent advances in cellulase technology. Ferment. Technol. v. 54, p. 256-286, 1976.

MOSIER, N., WYMAN, C.; DALE, B.; ELANDER, R.; LEE, Y. Y.; HOLTZAPPLE, M.; LADISCH, M. Features of Promising Technologies for Pretreatment of Lignocellulosic Biomass. Bioresource Technology, v. 96(6), p. 673-686, 2005.

RODRÍGUEZ-ZÚÑIGA, U. F.; BERTUCCI NETO, V.; COURI, S.; CRESTANA, S.; FARINAS, C. S. Use of Spectroscopic and Imaging Techniques to Evaluate Pretreated 
Sugarcane Bagasse as a Substrate for Cellulase Production Under Solid-State Fermentation. Applied Biochemistry and Biotechnology. v.172, p. 2348-2362, 2014.

SINGH, R.; VARMA, A. J.; LAXMAN R. S.; RAO, M. Hydrolysis of cellulose derived from steam exploded bagasse by Penicillium cellulases: Comparison with commercial cellulose. Bioresour Technol. v. 100, p. 6679-6681, 2009.

SUKUMARAN, R. K.; SINGHANIA, R. R.; MATHEW G. M.; PANDEY, A. Cellulase production using biomass feedstock and its application in lignocellulose saccharification for bio-ethanol production. Renewable Energy.v. 34, p. 421-424, 2009.

WYMAN, C. E.; BALAN, V.; DALE, B.; ELANDER, R. T., FALLS M.; HAMES, B., HOLTZAPPLE, M. Y.; LADISCH M. R.; LEE, Y. Y.; MOSIER, N.; PALLAPOLU, V. R., SHI, J.; THOMAS S. R.; WARNER RE. Comparative data on effects of leading pretreatments and enzyme loadings and formulations on sugar yields from different switchgrass sources. Bioresource Technology. v. 102, p. 11052-11062, 2011.

XIMENES, E.; KIM, Y.; MOSIER, N.; DIEN, B.; LADISCH, M. Inhibition of Cellulases by Phenols. Enzyme and Microbial Technology, v.46, p.170-176, 2010.

XIMENES, E.; KIM, Y.; MOSIER, N.; DIEN, B.; LADISCH, M. Deactivation of Cellulases by Phenols. Enzyme and Microbial Technology, v. 48, p. 54-60, 2011. 